УДК 821.163.41.09(497.4)

https://doi.org/10.18485/msc50.2019.1.ch65

Владимир Б. Осолник

\title{
О АНТОЛОГИЈИ НОВИЈЕ СРПСКЕ ЛИРИКЕ БОГДАНА ПОПОВИЋА И ЮЕНИМ ОДЈЕЦИМА У СЛОВЕНИЈИ
}

\begin{abstract}
Овај рад разматра сродности и разлике међу књижевнокритичким оријентацијама српских, хрватских и словеначких антологија модерне лирске поезије. Истовремено рад испитује колико су научни приступ, књижевнотеоријски критеријуми и високи естетски стандарди Богдана Поповића у првој половини 20. века утицали на целокупну модерну јужнословенску литературу.
\end{abstract}

Кључне речи: естетичар Богдан Поповић, Антологија новије српске лирике, српска и јужнословенске књижевности.

Цењеном Међународном скупу слависта на Филолошком факултету Универзитета у Београду, где се под окриљем МСЦ-а већ 42. пут сусрећемо србокроатисти и србисти у Вукове дане, не треба посебно представљати књижевноисторијске токове кроз историју српске и јужнословенских књижевности, које су на свим подручјима и у свим раздобљима дале значајан допринос разноликости и богатству светске књижевности.

Ипак ћу поновити да је језик највеће достигнуће човечанства и да је књижевност, као уметност и логос речи, највеће достигнуће људског духа. Проистекла је спонтано из лирике, из осећајности, суптилности, наслућеног, доживљеног и подсвесног у бићу надареног појединца: кроз поезију, прозу и кретала се из загрљаја локалног окружења и етноса ка ширим, дубљим сферама етоса и врло ретко, у истанчаним достигнућима изузетних талената, корачала ка општим, универзалним, вечитим људским стањима, осећањима, мислима и делању. Тај пут од митоса, логоса, номоса и полиса, који је очигледан у литерарним процесима на свим континентима, прешле су и књижевности Јужних Словена, међу којима српска књижевност заузима видно, и, у минулим деценијама често, водеће место. Кроз усмену традицију и народне умотворине, познате целом свету заслугом Вука Стефановића Караџића, кроз властиту еру словенске писмености и старословенску средњевековну књижевност, и 
затим током XIX века, после храбрих победа оружја и ума у смелој српској револуцији, у пролећу европских народа, створила је своје препознатљиво национално биће и специфичну књижевност, односно темеље културе новог доба (Јован Скерлић).

У мноштву значајних достигнућа на пољу књижевности на српском језику, називаном по Јернеју Копитару у писмима Јакобу Гриму „Slavische SprachedesSerbo-CroatischesFolkes”,живисловенскијезикнепознатихјужнословенскихплемена сајугоистокадревног полуострваНаemosa-турски Балкана, као „Serbo-Croatische” или касније „serbocroatische sprache” од 1903. г. ${ }^{1}$ Истичу се мисли, стихови, творевине и издања, која су настајала заједничким трудом и акцијом родољубивих јужнословенских аутора, многа у Љубљани и у Загребу, крајем XIX и почетком XX века.

После оснивања првог савременог јужнословенског књижевног часописа „Коло” Станка Враза, после оснивања читаоница, новина, Матице хрватске, казалишта, Свеучилишта, Југословенске академије знаности и уметности, „Држављанског законика” - устава империје (у преводима Божидара Петрановића, Франа Миклошича, Димитрија Деметра и Вука Стефановића Караџића), бројних научних филолошких издања: „Граматике и стилистике хрватскога или српскога књижевног језика” Томе Маретића, „Хрватског правописа” и „Рјечника хрватскога језика” Ивана Броза и Фрање Ивековића, рада Ђура Даничића на речнику заједничког језика, уз утицајна дела Вука Стефановића Караџића, односно после достигнућа која су упркос организованом противљењу страних власти афирмисала свестрани потенцијал јужнословенских покрајина у различитим државним творевинама, штампана су и уметничка дела трајне вредности.

Међу тим далекосежно значајним остварењима јужнословенских аутора, чији је европски мисаони ход грубо прекинут избијањем I светског рата, својим интенцијама и богатством садржаја, високим интелектуалним видицима и снагом уметничког надахнућа, трајно интересовање и поштовање многих читалаца изазива Антологија новије српске лирике Богдана Поповића, ${ }^{2}$ издата на позив Матице хрватске у Загребу ${ }^{3} 1911$. г.

${ }^{1}$ Српскохрватски језик је као “Serbochroatische Schprache” изгласан и уведен законом у парламенту стране империје, Аустрије, за именовање језика у подручју новоосвојених словенских покрајина.

2 За ову прилику користио сам деветнаесто издање Српске књижевне задруге, Београд, 1996, и моји цитати су узети из те књиге.

3 Централно место јужнословенског културног живота на крају XIX и на почетку XX века постао је Загреб: тековине „пролећа народа” и националних покрета са територија Војне крајине и истовремених социјалних захтева „мартов- 
Стогодишњица тог издања била је и повод овом мом прилогу и прилика да изразим своје поштовање цењеном професору Богдану Поповићу.

Њена садржина, оригиналност, разноврсност, уметнички индивидуалитет у стиховима, и научни, естетски критеријуми изнети и у њеном „Уводу”, Европи су открили савремени фонд српске и јужнословенске књижевности, а јужнословенским народима уз то поставили путоказе ка оригиналним и спонтаним естетским вредностима, које из искреног властитог српског, јужнословенског, етничког и етичког круга воде у естетски круг универзалности.

Антологија новије српске тирике није настала случајно. Многи јужнословенски интелектуалци удружили су тада своје снаге и у организованом патриотском напору градили нову словенску заједницу, трудећи се да у свему буде слободна и, наравно, равноправна са тада већ формираним или истовремено настајућим европским државама и њиховим књижевностима.

Богдан Поповић, студент француске, тада најзначајније научне мисли у свету, у феудални свет стране империје увео је свој високи естетски критеријум и својим истанчаним избором од 169 песама 26 аутора из неколико хиљада прочитаних текстова ${ }^{4}$ створио незаобилазну уметничку творевину, у правом смислу изворне грчке речи, цветник поезије на српском односно српскохрватском/хрватскосрпском језику, који је послужио као узор за многе касније сличне покушаје на јужнословенском тлу.

Наиме, понукан тим издањем, у кругу надарених песника из хрватских покрајина, у којем је доминирао њихов Раби (учитељ), Антун Густав Матош, настао је наставак, допуна или специфичан одговор на књигу српске лирике, под импресионистичким, симболичким, когнитивним, данас би рекли знаковитим насловом Хрватска млада лирика (Загреб 1914), управо уочи светске ратне апокалипсе. Млади Љубо Визнер, уредник те лепе књиге, за њен наслов узима једну од квалификација Богдана Поповића, придев „млада” из Предговора Антологији (стр. 7 и 20) и реализује његову тезу, да антологија треба да представља заокружену целину стваралаштва из одабраног периода (иб., с. 11), а у свој „пре-

ске револуције” у том су универзитетском граду покренуле уметничку сарадњу између покрајина са различитим етничким јужнословенским заједницама, између хрватских, словеначких, српских и босанских писаца, под окриљем самосталних установа, Свеучилишта, Академије и Матице, и у бројним књижевним листовима.

${ }^{4}$ У својим Напоменама уредник Б. Поповић наводи прочитана издања, књиге, збирке, ревије и часописе, које је консултовао за свој ужи избор: избројао сам 98 наслова, са још већим бројем јединица. С. 335-6. 
глед младе хрватске поезије” уводи као примарни критеријум, супротно професору Б. Поповићу, спонтани, индивидуални, искључиво емотивно мотивисани лични приступ самог аутора. Наиме, песнике из хрватских крајева аустроугарске империје позива да сами изаберу неку од својих песама, према властитој субјективној оцени вредности и значења, мада о објективности те компетенције аутора професор Поповић изражава одређене, оправдане благе сумње (Предговор, с. 23). Истовремено, Визнер реализује мисао А. Г. Матоша, „протуножца” Јована Скерлића и жустрог противника научних, објективних погледа на књижевност, дакле и ставова Богдана Поповића, који такође сматра да се естетске вредности могу потврдити теоријско-књижевном анализом и протумачити применом научних инструмената, односно објективним разлозима (Предговор, с. 21).

Како је познато, Визнер је својом антологијом од 97 песама из пера 12 хрватских песника остварио обимом скромну (157 страница), веома значајну, незаобилазну слику стваралачких успеха, поступака и индивидуалних уметничких преокупација њихових разноликих аутора. Недостајање анализе и књижевно-критичких тумачења, које кореспондира са доследно спроведеним ставовима анализе „ред-по-ред” професора и естете Богдана Поповића, само по себи представља Визнеров оригинални, спонтани уметнички чин, а уводна реч својим песничким, емоцијама набијеним текстом необичну иновацију, апотеозу безграничне слободе, еруптивног елементарног талента, пожар страсти и бола у садашњости (Хрватска млада лирика, с. 6), и истовремено изазов читаоцима и будућим антологичарима да се определе за један од два различита уредничка приступа.

Са значајним временским закашњењем од 22 године на крајњем западу словенских територија, у Љубљани, штампана је, несумњиво под снажним утицајем Антологије новије српске тирике и ставова Б. Поповића, које нису могли умањити ни грозоте светског рата, прелепа антологија Содобна словенска лирика (Словеначка савремена тирика) (Југослованска књигарна, Љубљана 1933). Посматрана у низу јужнословенских духовних остварења $^{5}$ она одражава мисао да поезија и посебно лирика садрже и репрезентују читав спектар опште књижевности, и да песници и писци представљају најсвесније делове народа, и тако допуњава јужнословенски стваралачки круг.

${ }^{5}$ Непосредно пре Антологије новије српске тирике, Матица хрватска у Загребу је 1910. објавила Алманах српских и хрватских песника и приповедача. 
Интересантно је да антологија није плод надахнућа и сазнања једног аутора: настала је трудом двају угледних књижевних историчара; уредник песник Антон Водник ${ }^{6}$ изабрао је песме, написао сажету напомену уредника и саставио садржај, док је обиман и детаљан литерарно-теоретски „Увод” написао слависта, археолог и етнолог Рајко Ложар, ${ }^{7}$ продоран критичар књижевности и сликарства, потакнут филозофским ставовима Изидора Цанкара и Франа Вебера, чувеног професора филозофије са словеначког универзитета алма матер Александрина у Љубљани, који се у Европи сматрао водећим познаваоцем процеса настајања уметничких остварења у периоду између два светска рата. ${ }^{8}$

Оба словеначка аутора узимала су у обзир ставове Богдана Поповића и његових следбеника. Као и Б. Поповић они су прекинули са вековном класичном традицијом и афирмисали „нешто ново”.

Желели су да заинтересованој јавности представе живо стваралаштво тадашњих песничких генерација у периоду од 35 година, од већ афирмисаних песника модерне до најмлађих учесника у живим литерарним токовима, и да поведу своју читалачку публику у духовни свет лепоте и поезије (Б. Поповић, Предговор, с. 29; А. Водник, Уредникова опомба, с. 235).

Поповићева књига обухвата 354 страница, а словеначка 250: књижевно-теоретски увод Рајка Ложара на 53 стране (I-LIII) са шест поглавља (I-VI); Предговор Богдана Поповића подељен је на осам поглавља (I-VIII); кратку напомену уредника Антона Водника („Уводна опомба”, стр. 235), избор од 196 песама из пера 40 аутора, њихове фотографије и садржај, „Казало” (стр. 237-242). Не доноси био-библиографске податке о ауторима: наводи само годину и место рођења. Обухваћен је период од три деценије XX века, али се у Уводу, уз тумачење појединих уметничких поступака и песама, разматрају интенције и достигнућа старијих

${ }^{6}$ Видети: Slovenski biografski leksikon, IV/2, Ljubljana 1986, s. 503-506: „Vodnik Anton, pesnik, esejist in umetnostni zgodovinar ...Izostreni literarni okus in natančno poznavanje slovenske poezije je izpričal kot urednik antologije Slovenska sodobna lirika (1933, uvod Rajko Ložar), ki vsebuje izbrane pesmi predstavnikov različnih literarnih smeri od vključno moderne naprej”.

7 Видети: Enciklopedija Slovenije, k. 6, MK, Ljubljana 1992, s. 331-2: „Ložar, Rajko (Ljubljana 1904-Manitowoc, ZDA, 1985), arheolog, etnograf, umetnostni in literarni kritik... Med vojnama je v esejih in kritikah ocenjeval in uveljavljal predvsem sodobno likovno in besedno umetnost..." (Uvod v knjigo Slovenska sodobna lirika, urednik A. Vodnik, 1933).

${ }^{8}$ Своја сазнања објавио је у више научних студија, међу којима помињемо утицајну књигу Естетика, Љубљана 1925. 
генерација, на пример Франца Прешерна, Јосипа Стритара, Симона Грегорчича, Симона Јенка, Франа Левстика, Антона Ашкерца, да би се у фокусу херменеутичке анализе нашли Драготин Кетте-Михајлов, Јосип Мурн-Александров, Отон Жупанчич-Николајев, Иван Цанкар-Савељев, чијих песама има највише, а за њима и остварења млађих песника. Ту се појављују, на пример: Јожа Ловренчич, Антон Подбевшек, Миран Јарц, Антон и Франце Водник, Павел Голиа, Тоне Селишкар, Сречко и Стано Косовел, Цветко Голар, Божо и Витал Водушек, Едвард Коцбек, Миле Клопчич, Иван Албрехт, Иго Груден, Рудолф Маистер-Војанов, Војеслав Моле и најмлађи Богомил Фатур. Данак вековној традицији представља присутност једне једине песникиње, надарене Виде Тауфер, која је представљена са две песме („Завржено писмо”) и („Сречање с смртјо”, с. 191/2).

Уредник Антон Водник је написао 9 (превод је мој): „Овај избор жели да прикаже слику савремене словеначке лирике, тј. словеначког песничког стваралаштва од такозване модерне, коју представљају Кете-Мурн-Жупанчич-Цанкар све до најновијих дана, до задње стилне струје, у којој се већ јављају доста одређене контуре нове стварности". ${ }^{10}$ Затим објашњава да су песници односно њихова дела поређана у смисаоном развојно-ритмичком редоследу и према естетском критеријуму формалног савршенства и јасноће садржајног богатства и искрености надахнућа. Његов труд водила је тиха жеља да та књига постане Књига лепих тренутака, која ће духовно осетљивог и пријемчивог читаоца водити у свет лепоте... ${ }^{11}$

9 Словеначке текстове превео сам ради лакшег разумевања на српскохрватски/хрватскосрпски односно српски штокавско-екавски језик: словеначки текстови дати су испод главног текста. Све разлике између словеначког оригинала и цитираног превода, односно могуће грешке, које нарушавају мисао аутора, морају се приписати мојој некомпетентности. Владимир Осолник.

10 „Pričujoči izbor hoče podati sliko sodobne slovenske lirike, to je slovenskega pesniškega ustvarjanja od tako zvane 'moderne', ki jo zastopajo Kette-Murn-CankarŽupančič, pa do najnovejših dni, do zadnje stilne struje, v kateri se že javljajo precej določni obrisi 'nove stvarnosti..."

11 „Pesniki, ki so v tej antologiji zastopani, si slede torej v nekakem razvojno-ritmičnem redu, ki je samo tu pa tam nekoliko pretrgan in nedosleden (...) pri izbiranju posameznih pesmi mi je bil merodajen predvsem estetski kriterij formalne dognanosti in prozornosti ter vsebinske polnosti in pristnosti (...) Nazadnje naj še izdam skrito misel, ki me je ves čas spremljala pri tem dostikrat tudi mučnem izbiranju, primerjanju in tehtanju, naj bi bila pričujoča antologija predvsem nekaka Knjiga ur, ki naj bi duhovno sprejemljivega bralca $\mathrm{v}$ trenotkih zbranosti vodila skozi svet lepote k virom lastne sproščene človečnosti” (Urednikova opomba, s. 235). 
Свој избор отворио је песмом Драготина Кетеа „Izprehod”, „Шетња”, 12 а закључио ју је са песмом припадника најмлађе словеначке песничке генерације Богомила Фатурја „Плесалчев гиб”, „Покрет плесача”; ${ }^{13}$ његов поступак потсетиће нас на „Уводну песму” Јована Дучића и „Завршну песму” Милете Јакшића, које уоквирују ранији Поповићев избор.

Естетичар $^{14}$ Рајко Ложар у уводу тумачи законе уметности и инсистира на развоју стилова у словеначкој књижевности, тачније поезији. Као познавалац европских токова, он у ликовној и књижевној критици гаји филозофску и литерарно-теоретску мисао, утемељену у актуалним европским делима, и - као и Богдан Поповић - своју пажњу усмерава на потицај, настајање, симболику и хармонију у поезији, и наглашава њен субјективни импресиони-стички карактер и лирско одражавање изабраних тренутака у њој. Развојни лук словеначке поезије он посматра кроз стварање три генерације песника из 1900, 1910. и 1920. године и кроз фазе доминације симболизма, експресионизма, социјалне мисли, верског заноса, које су довеле до експериментисања младе, још неафирмисане, непрофилисане генерације најмлађих аутора.

У суштини Рајко Ложар прихвата све битне поставке, које је навео Богдан Поповић у свом Предговору Антологије новије српске тирике, I и VII издање $(1911,1936)$, и шире тумачи, односно, наставља лапидарно формулисано естетско усмерење Богдана Поповића, те даје шире теоријско образложење својих погледа на уметничко стварање, који додатно потврђују важну улогу естетског, из шест поглавља (I-VI) (Предговор Богдана Поповића подељен је на осам поглавља) и индивидуалног доживљаја у настајању и код поновног доживљавања поезије, уметности речи и уметности уопште. Ставове Богдана Поповића прилагођава спе-

12 Прва строфа гласи:

„V tiho samoto se kradejo, sijejo

Polni nemira in polni mladosti

Solnčni plameni, in ljubko se vijejo

Lahki zefiri, ootroci prostosti ..."

13 Прва строфа гласи:

„Ob kretnji vijočih se rok

Mi duša z vso grozo sluti:

Niti v najvišji minuti

Ne bomo v sebi krog...”

${ }^{14}$ Према Лексикону страних речи и израза, Милана Вујаклије, Просвета, Београд 1970: „естетика: наука о чулном опажању; у ужем смислу: наука о лепом, нарочито о уметности као најпотпунијем изражају онога што је лепо, наука о смислу за уметност и о уметничком укусу", с. 310. 
цифичној словеначкој ситуацији, ограничава период обухваћен схватањем слободне словеначке лирике, који директно кореспондира са Поповићевим изразом „новија српска лирика”, са већ поменутим водећим естетским критеријумом, са схватањима о нужном јединству садржаја и форме, са захтевом да песма цела мора бити лепа, са захтевом да мора бити јасна и да мора садржавати снажну емоцију, „искру”, поезију. Али уз све те тада већ проверене књижевно-критичке мисли Б. Поповића, уз потврду ставова да се поезија и уметност могу и морају анализирати и тумачити применом научног апарата и објективним разлозима, а не више идеалистичким критикама и божанским надахнућем, Ложар исцрпно, интерпретативним методом објашњава мотиве и стихове аутора: у детаљну анализу уводи свој лични и иновативни термин: „лик песме” и духовно, односно пресудно, комплексно „настројење” песника и његових читалаца.

Конкретније: Ложар луцидно наглашава значај књижевно-теоријских елемената у књижевној историји и истиче посебно место лирике међу књижевним врстама: наглашава њен специфичан карактер, који ју одељује од осталих прозних врста и истовремено ограничава њене домете; ${ }^{15}$ заузима се за искорак критике од „старог начина мишљења у духу природно-математичког енциклопедизма"16 и тврди да је лирско песништво посебна врста књижевног стварања са њему својственим предметом и субјектом, и тумачи га складно са променама у „данашњим схватањима естетских творевина". ${ }^{17}$

Даље, словеначки историчар књижевности у свом тумачењу улоге и садржаја антологије негира мисао натуралистичке естетике да је лирска песма песничко утеловљење материјала, описивање пејзажа, животиња, светаца, властитих осећања, жалости итд., и позива се на мисли Емила Золе и Франсиса Вебера: смисао лирског песништва, као и целокупне уметности новог доба треба тражити изван сфера објективног записивања стварности. ${ }^{18}$ Као Б. Поповић о смислу уметности речи и умотворина уопште, и Ложар сматра да успела песма мора у целости бити лепа, и за

15 „Ložar u svom uvodu naglašava „njen posebni značaj, ki jo od ostalih (proznih vrst) loči in omejuje" (s. VII i VIII).

16 Дословно тражи „slovo od duha starega prirodoslovno usmerjenega enciklopedizma”.

17 Ложар тврди: „lirično ustvarjanje je posebna zvrst slovstvenega ustvarjanja $\mathrm{z}$ njej lastnim predmetom in subjektom, kar je vse v tesni zvezi s spremembami v današnjem nazoru o estetskih tvorbah".

18 „Smisel liričnega ustvarjanja, kakor smisel cele umetnosti novejše dobe je iskati povsod drugod, samo ne v objektivnem upodabljanju snovi”. 
целину доживљавања песме уводи свој термин „лик песме”, да би очувао њену слојевитост, многозначност, независну од конкретних елемената песме: „Лирска песма је лик, иреални лик... изграђен на властитим основама, међу које спадају елементи комплетног искуственог и неискуственог света (...) што су мање истините основе то је тај иреални лик јачи (...) Ми у песми доживљавамо целовит лик, који састављају елементи песме, доживљавамо невидљиву конфигурацију појединих елемената; кроз предметно значењски испуњене речи и ознаке ми поезију доживљавамо преко целовитости лика песме. Наш доживљај лирске песме зависи од доживљавања лика”. И даље: „Шта је тај лик по својој неформалној страни, шта је његова садржина? Први одговор гласи: настрој, настројење”. Дефиниција логично следи: „Лирска песма је изражено настројење”. ${ }^{19}$

Да би учврстио свој став Ложар објашњава: „Разлика између старог и новог значења овог појма лежи у следећем: стари појам је означен мотивски, док се нови односи на структуру, на опште стање уметничког битка у тренутку настајања песме и садржи conditio sine qua non лирског дела. Естетска вредност и правилност лирске песме зато зависи од правилности и присутности осећања. Ако се запитамо шта је мерило те отворености и искрености, одговор је кратак: то, да песма и у нама побуђује и ствара такво осећање, да доживљавамо песму, да поново доживљавамо ауторово осећање”.

Таква „симболична присутност очуване идеје песника јавља се у лепим поређењима, метафорама, али то је тек у другом плану. Првобитно осећање дато је већ у самој физиономији песме, у њеном лику... Симболичка скривеност осећања за наше поновно доживљавање изражена је у недељивости значења и звука, која у органској оригиналности приказује не само садржај ситуације већ доноси и њену боју, њен тон, њену природу. Код неког другог аутора стил је осећања другачији, везује се за оригиналан, јединствен, вишеструко испреплетан ритам значења и мелодије, који удружује све елементе у слику хармоничног бића". ${ }^{20}$

19 Ту наводи песму Станка Мајцна, с. IX.

20 Ложар тврди: „Razlika med starim in novim pojmom je tedaj ta, da je stari pojem motivično označen, medtem ko se novi nanaša na strukturo, na splošno stanje umetniške biti $v$ hipu, ko pesem nastaja ... in vsebuje conditio sine qua non liričnega dela.Estetska polnovrednost in pravilnost lirične pesmi je zato odvisna zlasti od pravilnosti in prisotnosti nastrojenja. Ako se dotaknemo vprašanja, kaj je merilo take pristnosti, je odgovor kratek: to, če lirična pesem tudi v nas ustvari takšno nastrojenje, to se pravi, da jo doživimo, da avtorjevo nastrojenje ponovno doživimo”... „Simbolna shranjenost se javlja v lepih primerah, metaforah, toda šele v drugi vrsti. Prvotno je nastrojenje dano že v sami fiziognomiji pesmi, v njenem liku" S. X. 
И даље: „Песничке изразе треба тумачити као симболе осећања, који су записани зато да наша душевност уз њих затрепери баш у истом егзистенцијално-историјском осећању које је захватило и испуњавало песника. Природа, материја, само је основа и средство изражавања”."21 Као пример наводи Прешернов стих из епа „Крст при Савици”22: „Слика из Прешернове поезије тада је била слика, лик и илустрација, као на пример стара, уоквирена слика Делакрое: изражавала је везаност класичног човека на класичну академску мисаоност, која нестаје пред надирањем новог субјективизма нашег доба. Наш доживљај лирске песме има, дакле, свој предмет мимо материје, има свој властити предмет, који је израз целе светске ситуације и бити човека". 23

Прелазећи појединачно на ауторе из Водникове антологије, Ложар пише: „Ова антологија словеначке лирике најновијег доба почиње са именима Драготина Кетеа, Јосипа Мурна, Отона Жупанчича и Ивана Цанкара. Ту четворицу уметника обично наводимо као зачетнике и утемељиваче модерне словеначке књижевности... Њихове 'четири збирке (поезије, В. О.) представљају четири камена темељца савремене словеначке лирике и почетак стваралачког богаства, које нам је песнички геније дао у наредним деценијама". ${ }^{24}$

${ }^{21}$ „Simbolna skritost nastrojenja za naše ponovno doživetje se izraža v neločljivosti pomena in zvoka, ki v organični izvirnosti prikazuje ne samo vsebino situacije, nego tudi njeno barvo, njen ton, njeno naravo. Pri drugem avtorju je stil nastrojenja drugačen, veže ga enovit, prepletajoč ritem pomena in melodije, združujoč vse v podobo harmoničnega bitja”. I dalje: „Pesniške izraze kaže tolmačiti kot simbole nastrojenja, ki so zapisani zato, da tudi naša duševnost ob njih zazveniv prav enakem eksistenčno-zgodovinskem občutju, kot se je to zgodilo s poetom. Narava, snov je samo podlaga in sredstvo izraza" S. XI.

22 Ложар је изабрао често цитирани стих из Прешерновог националног романтичарског епа „Крст при Савици”, 1826: „Okrog vrat straža na pomoč zavpije”, где се вокали ређају у ономатопејични израз страшне ситуације.

${ }^{23}$,... podoba iz Prešerna bi tedaj bila slika, podoba, na primer stara, uokvirjena slika Delacroixa, vezanost klasičnega človeka na klasično akademsko miselnost, izginjajoča $v$ navalu novega subjektivizma naše dobe. Naše doživljanje lirične pesmi ima tedaj svoj predmet mimo snovi, ima lastni predmet: izraz celotne svetovnonazorske situacije in biti človeka" (Ib., s. XI).

${ }^{24}$ „Pričujoča antologija slovenske lirike najnovejšega časa se pričenja z imeni Dragotin Kette, Josip Murn, Oton Župančič in Ivan Cankar. Te štiri umetnike imenujemo navadno tudi začetnike modernega slovenskega slovstva. S prispevki v revijah so se pojavili okrog leta 1986, prve samostojne zbirke njihovih pesmi pa so izšle leta 1899, 'Erotika' Ivana Cankarja in 'Čaša opojnosti' Otona Župančiča. Kette in Murn zbirk nista izdala sama, umrla sta mlada ob vstopu v novi, oživljeni svet našega pesništva in 
И да закључим: Богдан Поповић је својим образовањем и талентом рационално замислио Антологију новије српске лирике и својим суптилним избором и научном анализом остварио једно од незаобилазних књижевнокритичких и уметничких дела целокупне српске књижевности. Међутим, како смо видели, њено објављивање 1911. г. у Загребу не представља изолован српски културни догађај, или само изабрани српски књижевно-лирскиелитни дискурс, већ је то издање део ширег тока модернистичког европског и јужнословенског песничког и књижевно-историјског стварања, које је свој богати, разнолики уметнички израз задобило у заокруженим, уметнички успелим и веома утицајним антологијама лирике Богдана Поповића, Љубе Визнера и Антона Водника. Поменуте збирке српске, хрватске и словеначке поезије представљају прелазак књижевности јужнословенских народа и народа из предања заборављеног дивљаштва у Европи у духовно високу, оригиналну, сложену и суптилну индивидуалну модерну поезију. Тај смели искорак превазишао је вековно понављање хришћанских и апокалиптичних образаца, тема, нарације и трајне заблуде, које доносе неумерени јужнословенски култови историје, доминације и ограничености властитог етноса, диктат присутности колективног етоса: кроз нови, субјективни, савремени естетски принцип јужнословенски песнички дух закорачио је у сферу универзалног људског духовног света.

\section{ЛИТЕРАТУРА}

Деретић 1983: Јован Деретић, Историја српске књижевности. Нолит, Београд.

Grčević 1971: Franjo Grčević, Knjuževni kritičar u teoretičar Bogdan Popović. Zagreb.

Петровић 1986: Светозар Петровић, Облик и смисао. Списи о стиху. Матица српска, Нови Сад.

Popović 1996: Bogdan Popović, Antologija novije srpske lirike. Matica Hrvatska, Zagreb, 1911; devetnaesto izdanje, SKZ, Beograd.

Slovenska sodobna lirika. Jugoslovanska Knjigarna, Ljubljana 1933.

Slođak 1934: Anton Slođak, Slovensko slovstvo. Akademska založba, Ljubljana.

je Kettejevo delo izdal Anton Aškerc (1900), Murnovo pa Ivan Prijatelj (1903). Te štiri zbirke so štirje temeljni stebri sodobne slovenske lirike in pričetek onega bogastva, ki nam ga je v sledečih desetletjih pesniški genij dal." 
Станојевић/Лазаревић 2003: Малиша Станојевић / Слободан Лазаревић, Епохе и стилови у српској књижевности (ХІХ и ХХ век). Филолошки факултет, Београд / Нова светлост, Крагујевац.

Šicel 1997: Miroslav Šicel, Hrvatska književnost 19. i 20. stoljeća. Školska knjiga, Zagreb.

Frangeš 2003: Ivo Frangeš, Povijest hrvatske književnosti. Nakladni zavod Matice Hrvatske, Zagreb.

Wiesner 1914: Ljubo Wiesner, Hrvatska mlada lirika. Društvo hrvatskih književnika, Zagreb.

Vladimir B. Osolnik

ON ANTHOLOGY OF MODERN SERBIAN LYRICS BY BOGDAN POPOVIC AND ITS REFLECTION IN SLOVENIA

\section{Summary}

This article portrays the similarities and differences between literarycritical orientations of editors of Serbian, Croatian, and Slovenian anthologies of modern lyric poetry. At the same time it presents how scientific approach, literary theoretical criteria, and high esthetic standards set by Bogdan Popović in the first half of the $20^{\text {th }}$ century influenced the modern South Slavic literature. 